Science Life

\title{
STATE PRIEKUḶI PLANT BREEDING INSTITUTE - A CENTURY OF AGRICULTURAL RESEARCH AND PLANT BREEDING
}

\author{
Gunta Bebre, Maija Gaiḳe, Ilze Skrabule, Arta Kronberga, and Vita Gaiḳe \\ State Priekuḷi Plant Breeding Institute, Zinatnes iela 1a, Priekuḷ LV-4126, LATVIA; \\ ilze.skrabule@priekuliselekcija.Iv
}

\begin{abstract}
The State Priekuli Plant Breeding Institute (previously Wenden, Cēsis or Priekuli Experimental and Breeding Station) started its operation in 1913. The main aims of research have remained the same for the last century: to provide knowledge on crop management and to create crop varieties suitable to local growing conditions and farming systems, acceptable to consumer requirements. Supply to farmers of high quality seed material of cereals, potato, pea, clover and grasses is an essential part of the scope. Overall, 31 crop species have been involved in a wide range of studies. More than 100 different crop varieties have been bred since the beginning of the $20^{\text {th }}$ century. Potato varieties 'Brasla', 'Agrie Dzeltenie', winter rye variety 'Kaupo', pea varieties 'Vitra', 'Retrija', barley variety 'Idumeja' and several clover and grass varieties are widely grown in farmers' fields. The first hulless barley variety in the Baltic States, 'Irbe', and winter triticale variety 'Inarta' have been bred in the Institute recently. Long-term crop rotation trials have been run for more than 50 years. A number of outstanding scientists and agronomists have worked in the Institute: potato breeders E. Knappe and V. Gaujers, cereal breeders J. Lindermanis, M. Gaike, and M. Sovere, grass breeders P. Pommers, A. Apinis, and I. Holms, pea breeder M. Vitjažkova, researchers on crop management $R$. Sniedze and V. Mikelsons, research manager and director $U$. Miglavs and others.
\end{abstract}

\section{INTRODUCTION}

The village of Priekuli is located on the western slope of the Vidzeme highlands near Cēsis, where the Gauja, Rauna and Vaive rivers create a picturesque landscape with scenic ravines and sandstone cliffs. The geographic location of Priekul,i is 57 degrees 19' $\mathrm{N}$ latitude and 25 degrees 20' E longitude.

The history of the State Priekuli Plant Breeding Institute reaches back to the beginning of the 19th century, when Latvian peasants started to organise unions to become more independent from the country's noblemen of German descent. Since the 18th century, the territory of Latvia was under the rule of czarist Russia, but the land still belonged to the German noblemen. At the beginning of the 19th century, when serfdom was abolished, Latvian peasants were able to purchase and own land, and they started to organise unions to become more independent. Latvian farmers started to realise the importance of crop testing under local conditions. The first agricultural society was established in 1906 as the Rìga Central Agricultural Society, when it began to organise trials and create a model farm.
PRIEKULI - A SELECTED LOCATION FOR AGRICULTURAL RESEARCH

It was not a coincidence that Priekul,i was chosen as the site for one of the agricultural centres. In the 1830s, reeve Jānis Krēslinšs rented the land in Priekuli, where he set up crop and vegetable variety trials, compared different soil fertilisation methods, tried new techniques for preparing soil, and experimented with different pest control methods. In 1838,119 potato varieties were tested, and the results were published the next year in Vidzeme's Agricultural Yearbook, which was printed in Terbata (today Tartu, Estonia) (Gaujers, 1983; Strods, 1992; Bebre, 2003c). In 1910, the Rìga Central Agricultural Society organised cereal, grass and root crop variety trials in Priekuli. The plan to establish an agricultural school in Priekuli was developed in 1839 (Strods, 1992), but, unfortunately, it took almost a century for the project to be implemented. Priekuḷi Agricultural School (now Priekuḷi and Jānmmuizas Agricultural Technical School) was established in 1910. The Baltic Agricultural Machinery Testing Station (now Certifying and Testing Centre) began operation in 1911, and the meteorological station in Priekuli recorded its first observations in 1912 (Anonymous, 1925; Anonymous, 1931a). 
When the Rīga Agricultural Central Society founded the research station in Priekuli, they asked the Agricultural Department for subsidies to send the first Director of the Station, Jānis Lūke, to Russia and Germany to learn about operation of similar types of stations (Anonymous, 1913).

\section{FIRST YEARS OF ACTIVITY}

In 23 April 1913, the Cēsis (or Wenden) Experimental Station (later Priekul,i Plant Breeding Station) was established on 44 hectares of land (Аноним, 1914). Since then, Priekul,i has become one of the most remarkable agricultural scientific and educational centres in Latvia. The same year, the Baltic Crop Pest Control Institute was also established in Priekuḷi (Eihe and Priekule, 2008).

Before field trials could be established, stumps and rocks had to be cleared from the land. Several experiments were set up: to determine the impact of fertilisers, to test the effect of one crop grown in one field for several years, to show the importance of planting material quality for potatoes, to estimate the impact of clover in rotation with cereals and vegetables, and other trials.

Jānis Lūke made first variety trials, with 11 barley and 16 oat varieties. He made selections of the best plants from local rye and barley populations, and he collected about 140 red clover plants (Аноним, 1914).

In 1914, J. Lūke left the position, and P. Stokmanis became the new Director of the Station, and J. Strazds, then a recent graduate from the Priekuli Agricultural School, became manager. At first, they focused their efforts on making all fields uniform in order to establish more accurate trials, and planted several crops, but mostly oats. The selection and seed propagation from rye, barley, oat and red clover populations were continued (Anonymous, 1915).

In the same year, the building of the Station's main office began, and equipment was obtained, including horse and harness, horse wagon and sled, scales, plough, cultivator and harrower. Land drainage was started by digging ditches, and it became necessary to increase the cattle herd for manure.

\section{IMPACT OF THE FIRST WORLD WAR}

The development of the Station was interrupted by the First World War in the fall of 1914. In 1915, the agronomist Augusts Kaksis became the Director of the Station, and continued to work in spite of the war. There were no active military operations in Vidzeme, but refugees came from all other parts of Latvia. Even the Rìga Central Agricultural Society office was re-located to Priekuli. In 1916, the editorial office of the periodical Baltijas Lauksaimnieks (Baltic Farmer) was also moved to Priekuli because of the war. In April 1918, Kārlis Ulmanis (one of the founders of the Republic of Latvia and the first Prime Minister of the new state, and the President of Republic of Latvia from 1934-1940.) was appointed as an editor of this paper, and worked in the Station's main building for several months (Anonymous, 1931a).
In 1917, all agricultural institutions in Priekuḷi (Agricultural School, Agricultural Machinery Testing Station, Meteorological Station, Pilot (model) farm and Breeding Station) were merged into one - Priekul,i Agricultural Institute, under the direction of the Central Agricultural Society; chairman of the Board was agronomist Viḷums Skubiņš. In December 1917, the Soviets occupied the majority of Latvian territory and confiscated everything at the Institute (Anonymous, 1931a).

\section{WORK FOR INDEPENDENT LATVIA FARMERS}

After the founding of the Republic of Latvia on 18 November 1918 and end of the war in 1919, the Priekuli Agricultural Experimental and Breeding Station was re-established. Kārlis Vīgants became the Director of the Station and led the reconstruction of buildings and other equipment destroyed during the war, and turned the land that was left uncultivated during those years into fertile and productive fields again. The variety testing for cereals, vegetables and potatoes was revived, and cereal and perennial grass breeding and seed production programmes were established. The main cereal breeding method continued to be repeated selection of single plants within varieties or landraces. In 1921, laboratory facilities and containers for seed sample storage were obtained, as well as a hand operated threshing machine. The equipment for planting and plant evaluation was built by the Station employees (Anonymous, 1922; Anonymous 1931a). During that year, 20 ha were added to the Station, and almost 1000 visitors came to the Station, including the head of the seed production association in Germany, and a professor from the Latvian University in Riga (Anonymous, 1922). In 1922, the construction of a new laboratory building was begun, and the library that mostly consisted of several reports from different Russian Experimental Stations was replenished with the necessary books and journals.

During the early 1920s, the new state of Latvia established regulations for seed growers, plant inspection and seed control (Anonymous, 1924).

The selection work with oats, barley, rye, winter wheat, timothy and red clover was expanded, and tests with meadow fescue and vegetable seed production were continued, as well as experiments with fertilisers. The situation became more complicated when agronomist A. Rubenis (director from 1923 to 1924) resigned in the beginning of 1923, and K. Vigants, who was the only plant breeder, also resigned in 1924.

In May 1923, Edgars Eglītis, an agronomist who specialised in potato production, assumed the position of Director of the Station with Pauls Gailitis as an assistant. 1 Forage agronomist Velta Pelce was working with meadow grasses. In 1924, she started to work with red fescue, French ryegrass, awnless brome grass, and white and alsike clover (Anonymous, 1925).

Priekuḷi Experimental and Plant Breeding Station in that year took part in agricultural exhibitions, and won several awards (Anonymous, 1925). 


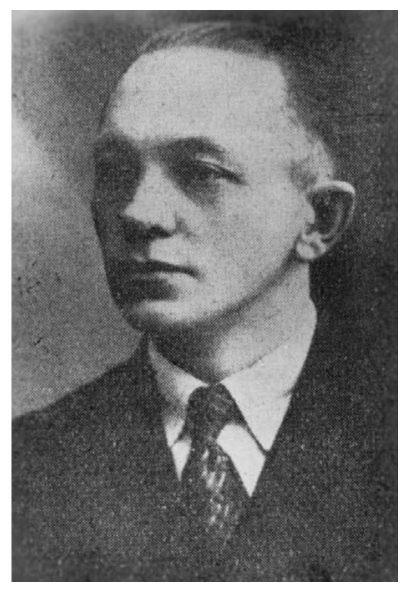

Edgars Eglītis, plant breeder and director 1923-1944

More laboratory equipment was purchased, including scales, seed germination equipment, a binocular microscope, tools for measuring spike length, stem width, as well as a seed grading (screening) and cleaning machine, seed planting equipment and special plough for test plots. More facilities were built, including a barn, a shed for threshing cereals and storing grain, a grain drying-house, a special seed treatment room, a basement and additional laboratory facilities.

As an industry, agriculture and livestock farming, especially pork production, was expanding, and potato consumption for feed increased, leading to a price increase. For that reason, potato production had become one of the most important tasks, and more trials were established, concentrating on quality and earliness. The taste and starch content in tubers was tested as well. E. Eglītis set up experiments with potato fertilisation and storage (Anonymous, 1925).

To protect winter cereals from snow mold, the first trials with rye seed treatment were started. Seed treatment and spraying experiments were conducted together with the Crop Pest Control Institute. Experiments showed that spraying potato with Bordeaux solution was important and that hilling of rows was necessary.

In 1925, six horses were used for work at the Station, but for ploughing the fields, a tractor was rented from the Priekuli Agricultural School. Acreage was 66 ha, of which 1.6 ha was for plant breeding, 1.5 ha for Crop Pest Control Institute experiments, and 1.8 ha for a vegetable garden and orchards. The Station operated on a crop rotation of ten fields. After forage breeder V. Pelce passed away in 1925, her work was continued by her former student, agronomist Erna Rozentāle, who conducted breeding of rye, spring and winter wheat, and barley (Anonymous, 1926; Anonymous, 1931a).

In May 1926, agronomist Nikolajs Brošs started to work as an assistant to the Director of the Priekuli Breeding Station, dealing with oat and red clover breeding and seed production. Trials were initiated to demonstrate the value of fertilisation to farmers (Anonymous, 1927; Anonymous, 1931a).

During those years, flax expanded to occupy a significant part of the export of agricultural production, but farmers usually were not able to reach quality standards. Trials for flax were set up at Priekuḷi, to determine the best growing conditions, locations, to compare populations, and plant selection was started for flax. In 1928, agronomist Pēteris Dreimanis started to work at the Station, setting up more experiments in flax production. Even four retteries were set up for flax processing (Anonymous, 1927).

In 1929, the first permanent technician was hired, agronomist Kārlis Lode. Prior to that, only students were used as labour during summer (Anonymous, 1931b).

By the end of the 1920s, the seed material of first varieties was being released from the breeding programmes at Priekuli: barley 'Vairoga', winter wheat 'Priekuli', winter rye 'Priekulii', spring oat 'Vainaga' and 'Priekuḷu baltās' (Table 1), and late timothy (Anonymous, 1931a; 1931b; Anonymous, 1937; Strazdina, 2012; Bebre, 2003c; Holms, 1992).

By 1930, 42 publications had been published in Latvian Agricultural Reviews and Agricultural Monthly Magazine. Agronomists gave talks at farmers meetings, exhibitions, and on radio.

In 1931, several significant changes took place: the work with potatoes was expanded, and the Department of Potato Breeding was established. Well-known potato breeder, Ërihs Knappe, came to work at Priekuli, bringing with him his breeding material and varieties (Anonymous, 1932; Gaujers,

Table 1

CEREAL VARIETIES DEVELOPED IN PRIEKUL̨I

\begin{tabular}{|c|c|c|c|}
\hline Species & Latin name & Variety & $\begin{array}{c}\text { Year of imple- } \\
\text { mentation or } \\
\text { registration }\end{array}$ \\
\hline \multirow[t]{4}{*}{ Winter rye } & \multirow[t]{4}{*}{ Secale cereale } & Priekuḷu & 1930 \\
\hline & & Vaive & 1967 \\
\hline & & Ārupe & 1982 \\
\hline & & Kaupo & 2001 \\
\hline \multirow[t]{3}{*}{ Winter wheat } & \multirow[t]{3}{*}{ Triticum aestivum } & Priekuḷu & 1927 \\
\hline & & Priekuļu 118 & 1953 \\
\hline & & Priekuḷu 481 & 1953 \\
\hline \multirow[t]{4}{*}{ Spring wheat } & \multirow[t]{4}{*}{ Triticum aestivum } & Priekuḷu & 1933 \\
\hline & & Priekuḷu & 1950 \\
\hline & & Priekuḷu 436 & 1964 \\
\hline & & Livva & 1971 \\
\hline \multirow[t]{13}{*}{ Spring barley } & \multirow[t]{13}{*}{ Hordeum sativum } & Vairoga & 1930 \\
\hline & & Priekuḷu 1 & 1959 \\
\hline & & Priekuḷu 60 & 1972 \\
\hline & & Ilga & 1982 \\
\hline & & Agra & 1984 \\
\hline & & Linga & 1992 \\
\hline & & Balga & 1995 \\
\hline & & $\mathrm{Rūja}$ & 1995 \\
\hline & & Gāte & 2000 \\
\hline & & Idumeja & 2002 \\
\hline & & Jumara & 2010 \\
\hline & & Rubiola & 2011 \\
\hline & & Irbe (hulless barley) & 2011 \\
\hline \multirow[t]{2}{*}{ Spring oat } & \multirow[t]{2}{*}{ Avena sativa } & Vainaga & 1931 \\
\hline & & Priekuḷu baltās & 1937 \\
\hline Winter triticale & Triticosecale & Inarta & 2012 \\
\hline
\end{tabular}


1983). The main breeding method was hybridisation between varieties. Potato cooking qualities were tested twice a year in November and June. The main focus was on potato "degeneration" (virus) problems and creating potato wart resistant varieties. E. Knappe concluded that under Latvian conditions it is possible in three years to "cure" any potato variety of all degenerating diseases, and produce disease free seed material. Seed material produced in Priekuli was well approved in Western Europe because of low "degeneration" or virus symptoms. Besides research on potato, trials were conducted within ten directions (programmes), including plant breeding, agro technical and fertilisation experiments (Bebre, 2003a).

During this time, researchers worked with quite a wide range of issues. A number of trials were established cooperatively with Stende Plant Breeding Station and other Latvian experimental stations (Holms, 1992; Zute et al., 2012).

In 1932, the acreage of the Station reached 260 ha, of which 190 ha was arable land. Now it was possible to produce more seed as well as to sell it, generating revenue to fund further research. The Director of the Station was N. Brošs, and the main manager was Emīls Pētersons. There were more than 100000 trial plots, including 5500 for potato and 2020 for flax.

Agronomist Arnolds Rullis replaced the previous flax breeder in 1933, and expanded flax breeding, which resulted in development of new improved varieties (Anonymous, 1934).

Trials were initiated with field beans, soybeans, lupin, hemp, and even sugar beets. An early maturing field bean variety 'Priekuḷu uzlabotās' was developed (Table 2) (Holms, 1992).

In the 1930s, the first potato varieties were offered for Latvia farmers: 'Eksports', 'Erna' (later 'Priekuḷ visagrie'), 'Zeltīte', 'Zīle', and 'Laimdota' (Table 3) (Gaujers, 1983).

Expansion of land drainage made it possible to start planting earlier and to obtain higher yields. In the 1920s, spring cereal planting was conducted after May 20, but in the 1930s, it was started at the beginning of May, or even at the end of April. During those years more equipment was purchased, including a "Fordson" tractor, a threshing machine, a "Petcus" sorting machine, and a "Saxonia" planter for trial plots, etc.

Variety trial plots and agro technical trial plots were sown with a horse-drawn sowing machine; smaller plant breeding plots were sown by a human-powered three-row planter. Cereal and grass plots were harvested by sickle, but seed production fields by scythe, then tied into sheafs and piled in stooks in the field to dry. Initially, a horse-drawn plough was used for potato harvesting; later horse-drawn, ground- driven rotating potato diggers were adopted.

In 1935, agronomist, and former technician, Kārlis Lode took over cereal breeding, using hybridisation as a main breeding method (Holms, 1992). Arvīds Sniedze worked as his techni-
Table 2

LEGUMES, BUCKWHEAT AND FLAX VARIETIES DEVELOPED IN PRIEKULI

\begin{tabular}{|c|c|c|c|}
\hline Species & Latin name & Variety & $\begin{array}{c}\text { Year of } \\
\text { realisation or } \\
\text { registration }\end{array}$ \\
\hline \multirow[t]{11}{*}{ Pea } & \multirow[t]{11}{*}{ Pisum sativums } & Priekuḷu 6 & 1950 \\
\hline & & Priekuḷu 81 & 1950 \\
\hline & & Rota & 1969 \\
\hline & & Aina & 1976 \\
\hline & & Vitra & 1994 \\
\hline & & Almara & 1991 \\
\hline & & Zaiga & 1999 \\
\hline & & Lāsma & 1999 \\
\hline & & Selga & 2001 \\
\hline & & Bruno & 2004 \\
\hline & & Retrija & 2004 \\
\hline Field beans & Vicia faba & Priekuḷu uzlabotās & 1935 \\
\hline Common vetch & Vicia sativa & Cēsu vietējie & 1950 \\
\hline Buckwheat & Fagopyrum esculentum & Priekuḷu & 1953 \\
\hline \multirow[t]{2}{*}{ Flax } & \multirow[t]{2}{*}{ Linum usitatissimum } & Priekuḷu uzlabotie & 1938 \\
\hline & & Priekuḷu 665 & 1938 \\
\hline
\end{tabular}

cian, but later moved to Stende, and began a successful career as a plant breeder (Zute et al., 2012).

During this time, the Latvian Agricultural Central Society disbanded, and Priekuli Station came under the management of Latvia Agriculture Chamber. The amount of work was expanding, and in 1935, Voldemārs Treknais started to work with perennial grasses - timothy, meadow fescue, annual and perennial ryegrass, red fescue, meadow-grass, white clover, and assembled an impressive wild grass collection as well, which included about 7300 local specimens (Holms, 1992).

\section{HARSH YEARS}

In 1939, potato breeder E. Knappe repatriated to Germany, and his work was continued by Rūdolfs Roze and Emīls Pētersons. Priekuḷi Plant Breeding Station continued to operate even during the Second World War, in spite of two occupations. At that time, the staff consisted of N. Brošs, R. Roze, K. Lode, A. Rullis, V. Treknais, P. Dreimanis, under the guidance of E. Eglītis. During the war, several varieties were developed: timothy, meadow fescue, and pasture ryegrass, which were purchased by a German company and taken to Germany (Holms, 1992). Potato and cereal seed material was produced and sold.

The most difficult time was in 1944, when the army of the Soviet Union invaded from the East. Researchers fled to the West countries in fear of Russian repression. The only breeder that stayed was Emīls Pētersons, and he rescued much of the potato breeding material and seed by providing alcohol to the army officials in exchange. Part of the spring wheat seed was rescued by Kārlis Lode and Jānis Bērziṇš by hiding it in a chimney (Bebre, 2003b). The rest of cereal seed 
Table 3

POTATO (Solanum tuberosum) VARIETIES DEVELOPED IN PRIEKULI

\begin{tabular}{|c|c|}
\hline Variety & Year of realisation or registration \\
\hline Agrie Smilšu & $1931-1940^{1}$ \\
\hline Lieldienolas & $1931-1940^{1}$ \\
\hline Priekuḷu Visagrie (Erna) & $1931-1940^{1}$ \\
\hline Laima (Klāra) & $1931-1940^{1}$ \\
\hline Spirtnieks & $1931-1940^{1}$ \\
\hline Zemgales Milži & $1931-1940^{1}$ \\
\hline Skaidrīte & $1931-1940^{1}$ \\
\hline Jelgavas Miltainie & $1931-1940^{1}$ \\
\hline Aurora & $1931-1940^{1}$ \\
\hline Eksports & $1931-1940^{1}$ \\
\hline Zìle & $1931-1940^{1}$ \\
\hline Agra & $1931-1940^{1}$ \\
\hline Balva & $1931-1940^{1}$ \\
\hline Vidzemes Vēlie & $1931-1940^{1}$ \\
\hline Spartaks & 1951 \\
\hline Zeltite & 1951 \\
\hline Laimdota & 1952 \\
\hline Agrie Dzeltenie & 1956 \\
\hline Priekuḷu Ražīgie & 1956 \\
\hline Priekuḷu Vēlie & 1956 \\
\hline Nākotne & 1957 \\
\hline Izstādes & 1960 \\
\hline Dzintars & 1961 \\
\hline Priekuḷu Baltie & 1967 \\
\hline Vita & 1968 \\
\hline Vidzeme & 1968 \\
\hline Jubileja & 1973 \\
\hline Astra & 1977 \\
\hline Gauja & 1977 \\
\hline Madara & 1992 \\
\hline Lauma & 1987 \\
\hline Sarmiņa & 1988 \\
\hline Skaidra & 1988 \\
\hline Zile & 1995 \\
\hline Brasla & 1995 \\
\hline Māris & 1992 \\
\hline Bete & 1999 \\
\hline Lenora & 2002 \\
\hline Sigunda (Unda) & 2002 \\
\hline Magdalena (Magda) & 2002 \\
\hline Monta & 2003 \\
\hline Imanta & 2008 \\
\hline Mandaga & 2010 \\
\hline Prelma & 2010 \\
\hline Gundega & 2011 \\
\hline
\end{tabular}

${ }^{1}$ The year of realisation was not stated.

\section{BREEDING STATION IN THE SOVIET UNION}

The first researcher after the war, who took over the work in December 1944, was Valfrīds Upmalis, and together with E. Pêtersons, they started to restore the operation. During the late 1940 Ss, the acreage was expanded to 371 ha by nationalising farmers land. Expansion continued and increased to 800 ha by 1949 when land was taken away (nationalised) from farmers by the Soviet government with the aim to create large Soviet collective farms (so called collectivisation programme).

In 1945, the Priekuli Plant Breeding Station was incorporated into the system of the USSR (Union of Soviet Socialist Republics) breeding stations, under the management of the Ministry of Agriculture, and everything had to be started from the beginning (Sniedze, 1973). Arnolds Hincenbergs was appointed as Director, and legume breeder Vasilijs Fedotovs and rye breeder Vasilijs Antropovs were sent from Russia to develop crop breeding in Latvia at Priekuli. They arrived to the Station with large legume and rye collections (Holms, 1992).

In 1947, an agrochemical laboratory was established at the Priekul,i Breeding Station by Rūdolfs Sniedze. Jāzeps Jaudzems was manager of the laboratory for a long period (19581985). Tests of soil compounds and different substances in

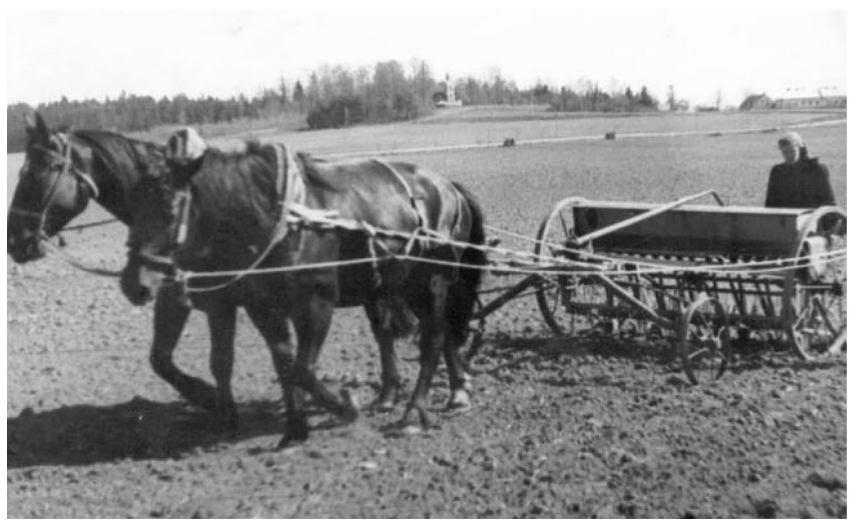

Sowing time, late 1940 s

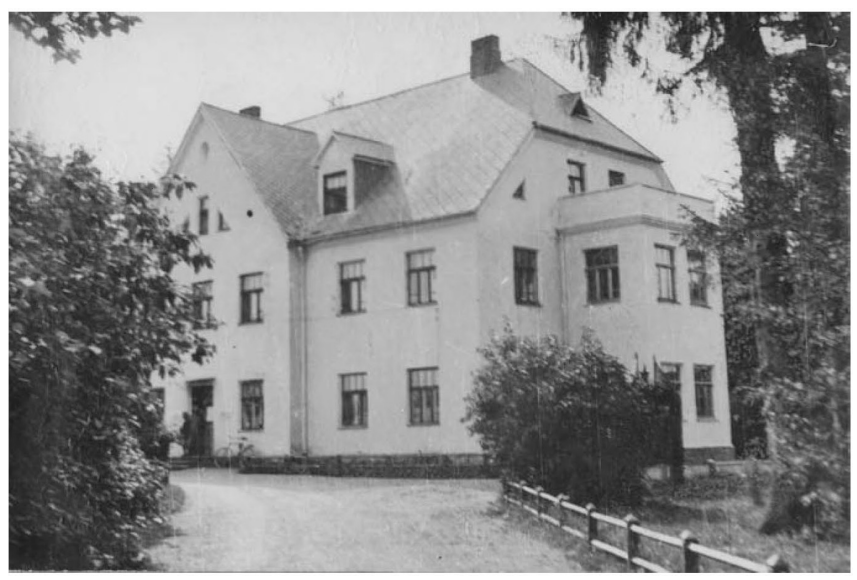

Priekul̦i Plant Breeding Station office and residential building constructed in 1915-1919, first building which was built specifically for the needs of station; used as office till 1977. was taken by the army. The Russian army took the best horses were rescued by hiding them in a nearby ravine. 
plants depending on fertilisation and vegetation periods were carried out (Zarina, 2003a).

Vasilijs Fedotovs' assistant Pēteris Pasečnuuks worked on pea breeding until 1951. By crossing different pea types (forms), he developed a type with reduced shattering, which was then named tenax. Later on, this type was the main trend in pea breeding, and became important breeding material for varieties developed in the USSR. From 1951 to 1958, Ansis Eglitis worked as a pea breeder, and P. Pasečnuks switched to buckwheat breeding. Aleksandrs Rozentāls (1958-1968) developed a pink flowered pea variety called 'Rota' (Table 2). Later, Alberts Apinis continued the breeding and developed tenax pea variety 'Almara' (Table 2). In 1984, pea breeding was continued by Maija Vitjažkova, and she developed several varieties with white flowers and light seed 'Selga', 'Lāsma', 'Zaiga' and with pink flowers and brown marble seed 'Bruno' and 'Retrija' (Table 2).

In 1953, an extensive collection of breeding material for red and white clover, and alsike clover was brought by Alberts Apinis when he came to work at the Station. During this time, the Soviet government approach was to replace clover with maize, and only the most fearless breeders continued to work with clover and sustained clover fields. A. Apinis finished breeding of red clover variety 'Priekulu 66' ('Raunis'), developed alsike clover varieties 'Priekul,u 26' and 'Priekul,u tetraploids' ('Namejs'), and the white clover variety 'Priekuḷ 61' ('Daile') (Table 4).

The spring cereal collection was re-established after the war by Arvīds Sniedze, who came back to Priekuḷi from Stende, and worked there until 1964. He developed an early six-row barley variety 'Priekulu 1', as well as several improved oat and barley lines. His work was continued by Maija Gaiķe, later together with Maija Sovere. They developed barley varieties 'Linga', 'Balga', 'Gāte' and 'Rūja' (Table 1), which were used for feed, food and malt production. From 1992 to 1999, geneticist Vita Gaik,e engaged in barley breeding and variety 'Idumeja' was released (Table 1).

A major success in perennial grass breeding was achieved by Pēteris Pommers (1945-1955), who developed several varieties: timothy 'Priekulu', meadow fescue 'Priekuḷ 519', Italian ryegrass 'Priekuḷu 32', meadow-grass 'Priekuḷ 129', and white bent-grass 'Priekulu 9' (Table 4). Grass breeder Valija Rēke completed the development of red fescue variety 'Priekulu 45' ('Vaive'), and Vilhelms Zeibots (1955-1982) developed the meadow foxtail variety 'Priekulu 40', as well as took part in developing the timothy varieties 'Priekul,u 2' ('Jumis'), oat-grass 'Priekul,u 20' and the pasture ryegrass variety 'Priekuḷu 59' ('Gunta') (Table 4). In 1966, Rūta Jansone joined the grass breeding programme, studying the cocksfoot grass collection and making crosses. Later, R. Jansone turned to initial seed material development and multiplication of grass and clover varieties. Ivars Holms (19662001) intensively studied and solved theoretical problems in perennial grass breeding, resulting in the new white bent-grass 'Priekuḷ', annual ryegrasses 'Iva' and 'Druva', meadow-grass varieties 'Gatve', 'Urga' and 'Dorete' (Table 4). In cooperation with the Skrīveri Research Institute of the
Table 4

CLOVER AND GRASSES VARIETIES DEVELOPED IN PRIEKUḶI

\begin{tabular}{|c|c|c|c|}
\hline Species & Latin name & Variety & $\begin{array}{l}\text { Year of } \\
\text { realisation or } \\
\text { registration }\end{array}$ \\
\hline Red clover & Trifolium pratennse & $\begin{array}{l}\text { Raunis (Priekuḷu } \\
66 \text { ) }\end{array}$ & 1968 \\
\hline \multirow[t]{2}{*}{ Alsike clover } & Trifolium hybridum & $\begin{array}{l}\text { Namejs (Priekuḷu } \\
\text { tetraploīdais) }\end{array}$ & 1977 \\
\hline & & Priekuḷu 26 & 1977 \\
\hline White clover & Trifolium repens & Daile (Priekuḷu 61) & 1977 \\
\hline \multirow[t]{2}{*}{ Meadow fescue } & Festuca pratensis & Priekuḷu 519 & 1956 \\
\hline & & Arita & 1995 \\
\hline Red cana rygrass & $\begin{array}{l}\text { Phalaris } \\
\text { arundinacea }\end{array}$ & Priekuḷu 4 & 1958 \\
\hline \multirow[t]{2}{*}{ Timothy } & Phleum pratensis & Priekuḷu & 1967 \\
\hline & & Jumis (Priekuḷu 2) & 1990 \\
\hline $\begin{array}{l}\text { Smooth brome } \\
\text { grass }\end{array}$ & Bromus inermis & Priekuḷu 13 & \\
\hline Tall oatgrass & $\begin{array}{l}\text { Arrhenatherum } \\
\text { elatius }\end{array}$ & Priekuḷu 20 & 1959 \\
\hline Cocksfoot & Dactylis glomerata & Priekuḷu 30 & 1959 \\
\hline Prenial ryegrass & Lolium perenne & Gunta (Priekuḷu 59) & 1959 \\
\hline $\begin{array}{l}\text { Westerwolds } \\
\text { ryegrass }\end{array}$ & $\begin{array}{l}\text { Lolium multiflorum } \\
\text { var. } \\
\text { Westerwoldicum }\end{array}$ & Druva (Uva) & 1994 \\
\hline Red fescue & Festuca rubra & Vaive (Priekuḷu 45) & 1959 \\
\hline Meadow fescue & Festuca pratensis & Arita & 1995 \\
\hline \multirow[t]{4}{*}{ Meadow bluegrass } & Poa pratensis & Priekulu 129 & 1959 \\
\hline & & Gatve & 1986 \\
\hline & & Urga & 2000 \\
\hline & & Dorete & 2004 \\
\hline Bog bluegrass & Poa palustris & Priekuḷu & 1959 \\
\hline Meadow foxtail & $\begin{array}{l}\text { Alopecurus } \\
\text { pratensis }\end{array}$ & Priekuḷu 40 & 1976 \\
\hline Red top & Agrostis alba & Priekuḷu 15 & 1972 \\
\hline
\end{tabular}

Latvian Agricultural University, he developed the tetraploid meadow ryegrass variety 'Spīdola'. Grass breeding in Priekuli was discontinued when Ivars Holms retired in 2001.

In the Forage Crop Department during the 1950s and the 1960s, several crops were tested for production in Latvia's growing conditions, including corn, root-crops, and completely new crops like Heracleum sosnowsky, comfrey (Symphytum officinale), mallow (Malvas), and knotweed (Polygonum weyrichii) (Bebre, 2003b).

In 1947, Jānis Lindermanis engaged in winter cereal breeding. Due to his accurate study of the population rye variety 'Priekulu' and successful selection, this variety was still grown in Latvia into the early 1990s. He developed a tetraploid rye variety 'Vaive' and winter wheat variety 'Priekulu 481' (Table 1), and was responsible for research in Priekuli Breeding Station during two periods: from 1956 to 1961 and from 1968 to 1981 . The rye breeding programme was continued by Edìte Lielbārde (1982-1990). At the end of the 1990s, the rye variety 'Kaupo' was developed (Table 1). 
Emīls Bērziņš continued spring wheat breeding from 1954, working together with Edìte Stūre and Maija Sovere. The spring wheat programme was interrupted in 1971.

In 1953, Augusts Krēslinšs took the position of Director of the Priekuli Breeding Station (until 1959), and was involved in research as well. From 1961 to 1962, Kārlis Sproga and later Voldemārs Kenne (1963-1967) were Directors of the Station (Bebre, 2003b).

In 1953, agronomist Vilis Gaujers moved from the Lejaskurzeme research station and took over management of potato breeding in Priekuli. The newest methodology was introduced in potato breeding and $\mathrm{s}$ eed production. The phytopathologists and agro-chemists were involved in assessment of breeding material. Resistance to main diseases and pests (late blight, viruses and bacterial diseases) was evaluated. The detection of viral diseases by serological testing of potato seed material was started in cooperation with researchers from the Crop Protection Institute. On the initiative of V. Gaujers, a set of laboratories, six greenhouses, hotbeds and storage areas for potato breeding were designed and erected in 1973. The facilities allowed expansion of breeding capacity and to run several research programmes in potato production and seed material production. V. Gaujers was involved in development of eleven potato varieties, and some of them are still popular — 'Agrie Dzeltenie', 'Laimdota' and 'Madara' (Table 3).

After termination of the Latvia Zonal Potato Breeding and Experimental Station in Carnikava, the potato breeder Aleksandrs Aņikijevs joined Priekul,i in 1963, bringing previously developed potato breeding material. He dealt with development of varieties suitable for feed and processing in starch. In 1977, the breeding work of A. Anikijevs was continued by Nanija Kesa, who was involved in improvement of potato seed production as well. Jānis Katajs-Paeglis (previously researcher of the agrochemical laboratory) took over the management of potato breeding in 1977. J. KatajsPaeglis introduced mechanisation in potato breeding and seed production, which reduced hard manual labour. Later, Marija Oša and Gunta Bebre joined the potato breeding work, both of whom previously worked with potato diseases. Important achievements of that time were the potato varieties: 'Brasla' — for starch production, 'Zīle', 'Skaidra', and ‘Astra' (Table 3) (Miglavs u.c, 1991).

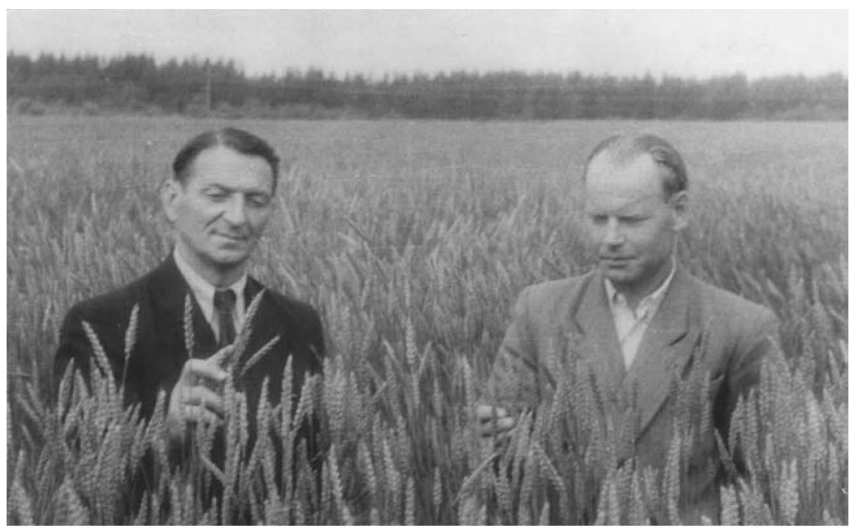

V. Upmanis and V. Mikelsons, researchers on crop management, 1960s

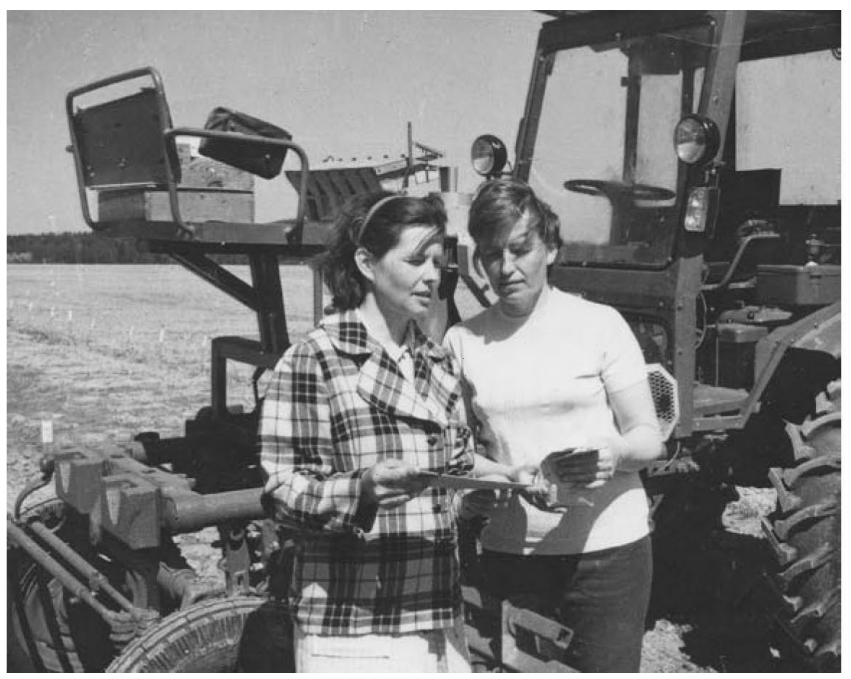

M. Gaike and M. Sovere, cereal breeders, 1970s

Research on crop management, crop rotation and soil fertility was an important part of the scientific work. Investigation of cereal sowing time and sowing rates was carried out by cereal breeders. The implementation of legumes and clover in crop rotation, soil fertilisation and tillage were studied. Andrejs Zirnītis was involved with investigation of soil fertility maintenance; Apolonijs Bratkovskis worked with testing of pesticide application. Potato cultivation was research agenda for Uldis Kḷaviņš.

A special long-term trial on crop rotation and soil fertilisation using manure and different rates of fertilisers was established by Vilnis Mikelsons in 1958. Since 1992, the work has been continued by Lìvija Zarina (Zarina, 2003b).

\section{SOVIET RESEARCH AND MODEL AGRICULTURAL FARM}

The acreage of the Station increased significantly in 1962 to 2335 ha when it was merged with adjacent collective farms. More and bigger facilities were needed, and impressive grain drying facilities and potato storage facilities were built. The Priekuli Breeding Station became a model collective farm in this region, and researchers had to deal with different agricultural and economical problem solving not only in the region, but throughout the Latvian Soviet Socialistic Republic (Anonymous, 1966; Sniedze, 1973).

Vladislavs Jurkāns was the Director of the Station for the longest period of time, from 1968 to 1985 . In 1976, the Priekuli Breeding Station became a large-scale, semi-commercial farm with 5624 ha acreage, by merging another collective farm. Extensive expansion included construction of new research laboratories, potato storage facilities, and cereal and grass seed drying facilities, livestock farms, a mechanical workshop, as well as apartment buildings, and an administrative building with a cultural centre and sports hall (Anonymous, 1983; Bebre, 2003b).

The main divisions of the Station as a research and commercial farm were: crop research and plant breeding (80 employees), crop seed production (100 employees), animal hus- 
bandry (80-90), mechanical (170), construction (80-90), infrastructure and support (70) (Anonymous, 1983). The Research Department Manager from 1982 was Uldis Miglavs.

Important changes were introduced in potato seed material production. The serological tests used in potato seed production for detection and removal of tubers with virusal diseases were laborious and time consuming. This method helped to remove diseased tubers, but when seed material was fully infected, the method did not do anything for elimination of infection. The laboratory of tissue culture was established in 1978 , with the aim to develop methods for elimination of virus diseases in potato and to establish production of healthy initial potato seed material. The development and adaptation of the methods to local conditions took ten years. As a result, the potato seed production system which had been started with virus-free in vitro plants has been implemented in Priekuli and in territory of Latvia since 1985 (Bebre, 2003b).

In 1985, Roberts Dilba became the Director of the Station. During his management the construction of the Priekuli High School and the last apartment building were completed; work was continued on a modern laboratory complex that was begun in 1984.

\section{SEARCHING FOR NEW OPPORTUNITIES}

In 4 May 1990, Latvia regained her independence, and significant changes had to be made in the Priekuli Breeding Station operation as well, since the nationalised land had to be returned to previous owners, and the funding from government sources decreased.

In 1995, R. Dilba was elected to a position in the Latvian Parliament (Saeima) and Uldis Lūkins took over the reins as the Station Director. His tenure coincided with chaotic agricultural times in Latvia, which caused a lot of turmoil for the personnel, as well as for the state. No one really knew how to organise the management of the Station, such that the situation would be sustainable. Several models were suggested, but they did not obtain the approval of the personnel. The era of privatisation including a not-entirely-legal acquisition had begun. Disapproval with the leadership style also began to brew. The next logical step was to split the Station into two divisions: research and production.

A major reorganisation and rationalisation of the Station occurred in 1998, when the State Priekul,i Breeding Station, with 215 ha of state land for research, breeding and seed production was set up under supervision of the Ministry of Agriculture. The overall number of employees decreased to the 70-80 full time research employees, and U. Miglavs was elected as Director. The main areas that remained were plant breeding, seed production and crop management research.

Young plant breeders joined the breeding programmes, bringing new up-to-date insights. The rye breeding programme was successfully continued by Aina Kokare. Triticale breeding was started in 1994 by Arta Kronberga. The first triticale variety in Baltic States 'Inarta' was registered in 2012 (Table 1). Ilze Skrabule, who previously dealt

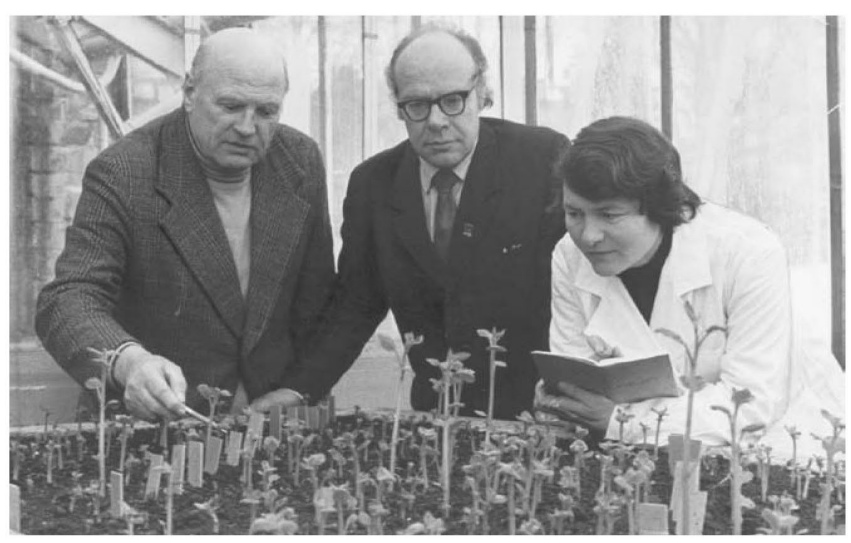

V. Gaujers, potato breeder, V. Jurkāns, researcher and director, J. Broka, potato seed producer, $1980 \mathrm{~s}$

with potato diseases, joined potato breeding in 1992; she focused breeding on quality traits. As a result of previous work, eight new potato varieties have been registered since 2000 (Table 3). The barley breeder Linda Legzdina was involved in development of hulless barley varieties; as a result the hulless barley variety 'Irbe' was created in 2012 (Table 1). Pea breeding was taken over by Skaidrīte Būmane. The laboratory of plant biotechnology and quality was established by molecular biologist Ieva Mežaka in 2007. Genetic tests and application of molecular markers became available for breeding purposes.

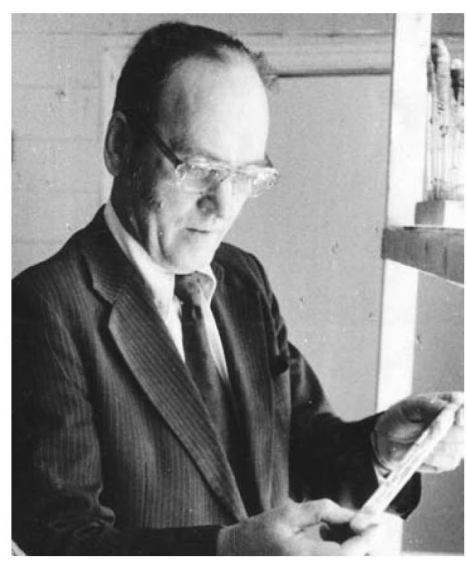

U. Miglavs, research manager and director, 1980s

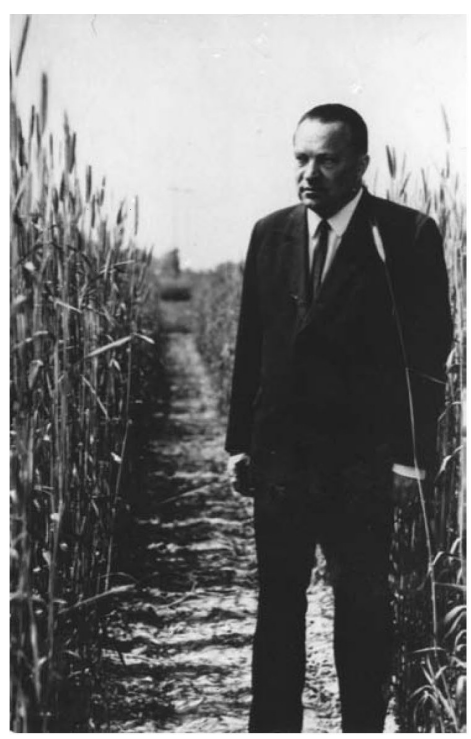

J. Lindermanis, cereal breeder, 1980 s 


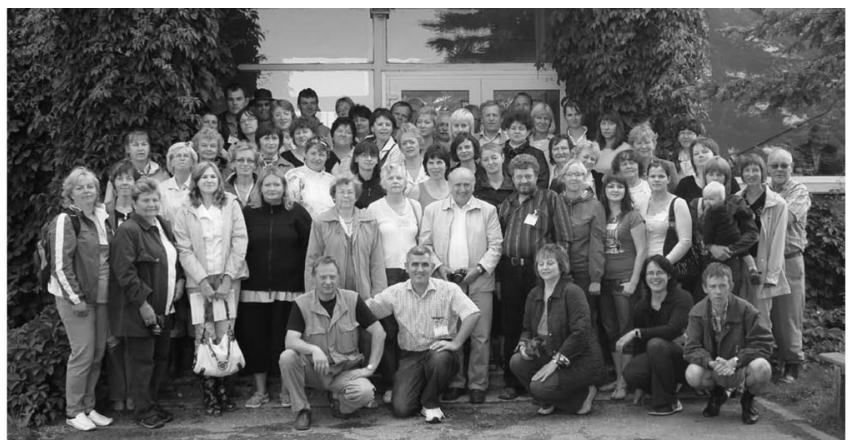

International scientific conference, 2003.

Research on organic farming was started in 2003, led by I. Skrabule. The assessment of crop varieties suitability for organic farming, methods of plant protection, and maintenance of soil fertility, were research directions at the beginning, and now are continued by Lìvija Zarina. Development of a breeding strategy for organic farming and development of assessment methods have been research tasks for breeders of barley, triticale and potato.

Research on competition between weeds and crops has been investigated by Dace Piliksere.

In 2006, the name of Station was changed to State Priekuli Plant Breeding Institute. Arta Kronberga was elected as director of the Institute in 2011. Nowadays, the institute employs around 60 persons including 15 researchers, three agronomists, technical and administrative staff.

Today, the mission of the Institute as a scientific institution is to create new knowledge, develop new products and innovative technologies, thus enhancing competitiveness of Latvian agriculture and sustainable rural development. Currently, the Institute has become one of the leading and most experienced Latvian research institutions in agricultural science.

\section{IMPLEMENTATION OF MAIN RESEARCH DIREC- TIONS}

An integral part of successful work in science is knowledge transfer to the international scientific society. For decades researchers of the Institute have closely collaborated with analogous scientific institutions of the Baltic countries. Scientific solutions are searched for in collaboration with researchers from the Netherlands, Germany, Sweden, Russia and other countries. Involvement in the European Research Area is focused mainly on organic farming, sustainable management and crop breeding for environmentally friendly farming. To improve breeding technologies, the fields of molecular biology and genetics are exploited. Innovative technologies are studied and implemented for plant quality trait detection.

Research projects have been carried out in the frames of several EU Programmes. Within several international programmes (CHANNEL, ECO-LOGICA, East etc.), system of exchange of information on organic farming in Europe has been established. Within a project funded by the INTERREG programme, studies using common methodology on reduc-

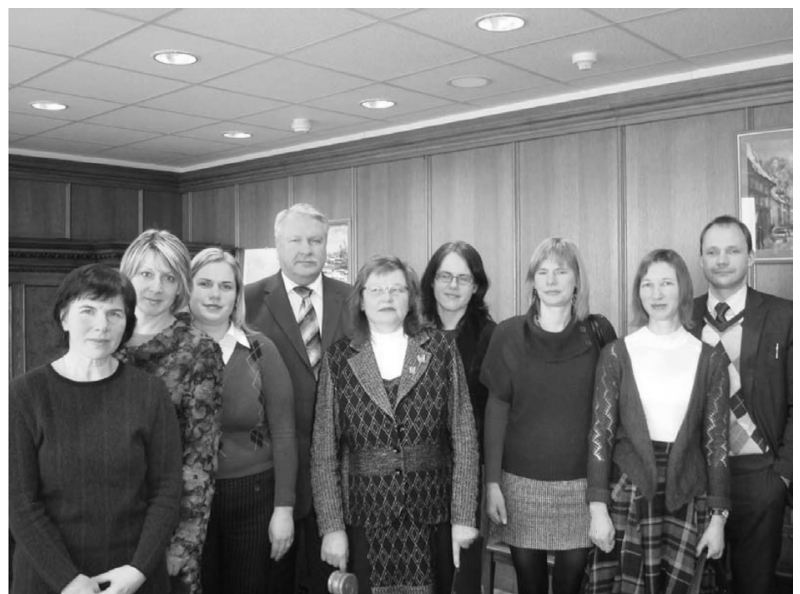

Visit of the Scientific Board of the Institute to the Minister of Agriculture 2011: L. Zarina, A. Kokare, S. Rozenberga, minister J. Dūklavs, I. Skrabule, D. Piliksere, A. Kronberga, L. Legzdina, N. Rostoks

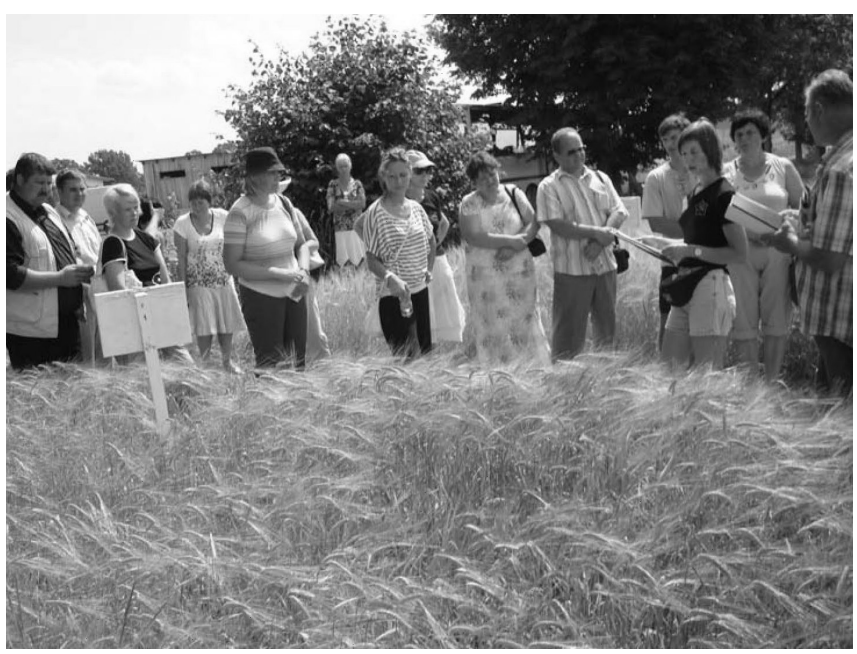

Field day in Priekuli, 2011

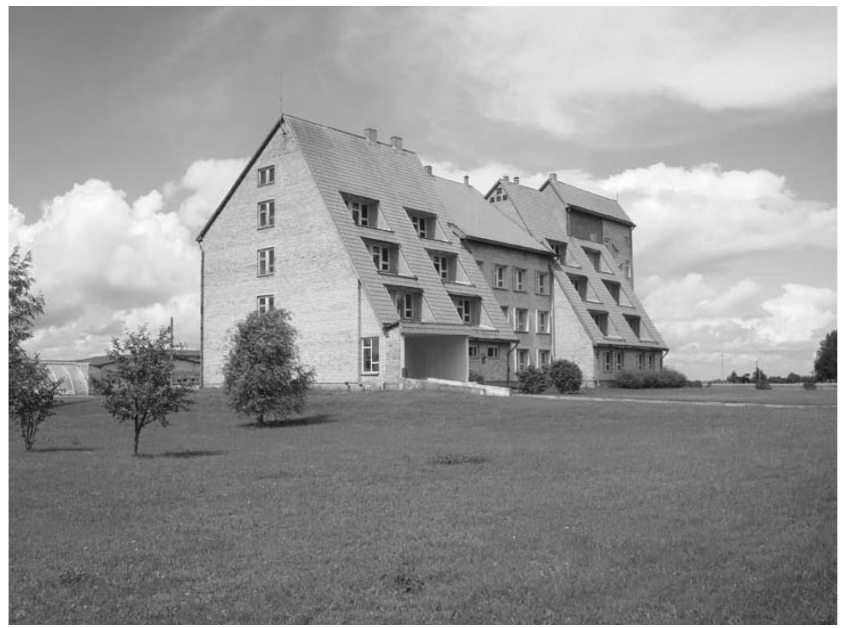

State Priekuḷi Plant Breeding Institute main building, 2013.

tion of pesticide emissions in the environment have been carried out. Institute researchers have been involved in several COST actions and participated in events related to grain crop genome research and breeding for organic farming. Within an EEA grant „Development of a crop breeding strategy for organic farming", trials for crop breeding in conventional and organic farming conditions have been performed. The 
studies have continued in the frame of the European transnational research cooperation project Core Organic II. Within a project funded by the Estonian Latvian programme ESTLAT, solutions to problems in the potato production sector and organic seed production are being sought.

The research project „Development, improvement and implementation of environmentally friendly and sustainable crop breeding technologies", co-financed by ESF (European Social Found), was initiated. A scientific group has been formed and conducting research on breeding methodology and selection schemes for crop variety breeding, detection of biologically active substances, molecular mapping of genes determining crop traits and development of molecular markers. The scientific group involves breeders, genetics, chemists and also researchers from the field of medicine. The results acquired on selection criteria for crop breeding for organic farming are important in the European Research Area.

The National Research Programmes promote research and development of state priorities.

Within the National Research Programme in Agrobiotechnology, a comprehensive genetical, biochemical and physiological analysis of Latvian crop varieties, breeding lines and hybrids has been conducted. Accessions have been evaluated to select ones most suitable for healthy food and production into innovative, high-quality products. Trilateral collaboration with researchers from the Institute and University of Latvia has resulted in phenotypic evaluation of potato and barley genotypes and these genotypes have been prepared for SNP genotyping with the further aim to use the information from both genotyping and phenotyping for association mapping. Also an experimental barley mapping population has been created.

Research on qualitative food production has been conducted within the project FOOD in the frame of the State Research Programme NatRes. The biochemical composition of barley, triticale and potato, as important considerations for human health, have been studied, in relation to cultivation technologies. Genotypes have been evaluated to identify those with elevated levels of compounds important for health (fibre, vitamin etc.) and thus suitability for use in food production. Special attention has been paid to food diversification: the hulless barley and triticale were included in development of food products, as well as potato with various flesh colours for specific diets. The investigation of plant compounds beneficial for health could promote breeding of varieties with elevated levels of such compounds. Work in implementation of NIR technologies for evaluation of breeding material has been initiated.

Several research directions have been supported by the Latvian Council of Science, Ministry of Education and Science, Ministry of Agriculture and producers. Maintenance, research and description of Latvian crop genetic resources had been made possible. In collaboration with the Genetic Resource Centre and other institutes involved in genetic resource conservation, a unified system for description of ge- netic resources has been elaborated. Possibilities to use molecular markers in seed production have been studied. Solutions to plant protection problems in organic farming conditions have been sought. Significant effort has been invested in development of a cereal plant defence system for integrated farming.

Crop management and soil research is one of the research areas of Institute and long-term trials have been set up and are being managed by precise crop management technologies and special crop rotation. In the same trial, weed research is being carried out.

In 2010, the most successful organisations of agricultural and food science, including the State Priekuli Plant Breeding Institute, united to form the National Centre for Agricultural and Food Research, with the aim to provide a scientific basis for sustainable and innovative agriculture and food industry. Under the umbrella of the centre, reciprocal collaboration will be stimulated and competitiveness of agricultural science will be raised.

The farmers and land owners from the territory of Latvia promoted development of agricultural research and plant breeding in Priekuli before an independent state had been established. The name and land area of the institution changed several times, but the main aims have remained the same during the last century: to provide knowledge on crop management and to create crop varieties suitable to local growing conditions and consumer demands. Several generations of plant breeders, researchers and agronomists have changed. Many people have devoted their work, thought and time to ensure scientific and commercial development of the Priekuli Breeding Station and later State Priekuli Plant Breeding Institute. Now it has become the leading and most experienced Latvian research institution in agricultural science. The acquired experience is an excellent investment for the future, and for promoting integration into agricultural science at the international level. As in past research, efforts in the future mostly will be taken to address the competitiveness of Latvian agriculture.

\section{ACKNOWLEDGMENTS}

Thanks to Prof. Emeritus D. Falk for essential help with English phrasing and style.

\section{REFERENCES}

Anonymous (1913). Rīgas lauksaimniecības Centrālbiedrības gada pārskats par 1912. gadu [Report on Activities of Rīga Central Agricultural Society during 1912]. Rīga: Vilks un Škinķis. 112 lpp. (in Latvian).

Anonymous (1915). Rīgas lauksaimniecības Centrālbiedrības gada pārskats par 1914. gadu [Report on Activities of Rīga Central Agricultural Society during 1914]. Rīga: Rīgas Lauksaimniecības Centrālbiedrības drukātava. 39 lpp. (in Latvian).

Anonymous (1922). Latvijas Lauksaimniecības Centrālbiedrības darbības pārskats par laiku no 1. janvāra 1921. g. līdz 1. maijam 1922. gadā [Report on Activities of Latvian Central Agricultural Society from January 1st 1921 till May 1st 1922]. Rīga: Latvijas Lauksaimniecības Centrālbiedrības drukātava. 253 lpp. (in Latvian). 
Anonymous (1924). Latvijas Lauksaimniecības Centrālbiedrības darbības pārskats par laiku no 1. maija 1923. g. lìdz 1. maijam 1924. gadā [Report on Activities of Latvian Central Agricultural Society from May 1st 1923 till May 1st 1924]. Rīga: Latvijas Lauksaimniecības Centrālbiedrības izdevums. 462 lpp. (in Latvian).

Anonymous (1925). Latvijas Lauksaimniecības Centrālbiedrības darbības pārskats par laiku no 1. maija 1924. g. lìdz 1. maijam 1925. gadā [Report on activities of Latvian Central Agricultural Society from May 1st 1924 till May 1st 1925]. Rīga: Latvijas Lauksaimniecības Centrālbiedrības izdevums. 313 1pp. (in Latvian).

Anonymous (1925). Priekuḷu Lauksaimniecības Institūts 1910.-1925. [Priekuli Agricultural Institute 1910-1925]. Rīga: Savienības „Latvijas Lauksaimniecības Centrālbiedrība” izdevums. 23 lpp. (in Latvian)

Anonymous (1926). Latvijas Lauksaimniecības Centrālbiedrības darbības pārskats par laiku no 1. maija 1925. g. lìdz 1. maijam 1926. gadā [Report on Activities of Latvian Central Agricultural Society from May 1st 1925 till May 1st 1926]. Rīga: Latvijas Lauksaimniecības Centrālbiedrības izdevums. 323 lpp. (in Latvian).

Anonymous (1927). Latvijas Lauksaimniecības Centrālbiedrības darbības pārskats par laiku no 1. maija 1926. g. lìdz 1. maijam 1927. gadā [Report on activities of Latvian Central Agricultural Society from May 1st 1926 till May 1st 1927]. Rīga: Latvijas Lauksaimniecības Centrālbiedrības izdevums. 343 lpp. (in Latvian)

Anonymous (1931a). Savienība „Latvijas Lauksaimniecības Centrālbiedrība” un vinas 25 gadu darbs [Society „Agricultural Society of Latvia” and its work during 25 years]. Rīga: Latvijas Lauksaimniecības Centrālbiedrības izdevums. 189 lpp. (in Latvian).

Anonymous (1931b). Priekuḷ Lauksaimniecības Institūts [Priekuli Agricultural Institute]. Rīga: Latvijas Lauksaimniecības Centrālbiedrības izdevums. 32 lpp. (in Latvian).

Anonymous (1932). Latvijas Lauksaimniecības Centrālbiedrības darbības pārskats par laiku no 1. maija 1931. g. lìdz 1. maijam 1932. gadā [Report on Activities of Latvian Central Agricultural Society from May 1st 1931 till May 1st 1932]. Rīga: Latvijas Lauksaimniecības Centrālbiedrības izdevums. 90 lpp. (in Latvian).

Anonymous (1934). Latvijas Lauksaimniecības Centrālbiedrības darbības pārskats par laiku no 1. maija 1933. g. lìdz 1. maijam 1934. gadā [Report on Activities of Latvian Central Agricultural Society from May 1st 1933 till May 1st 1934]. Rīga: Latvijas Lauksaimniecības Centrālbiedrības izdevums. 112 lpp. (in Latvian).

Anonymous (1937). Latvijas Lauksaimniecības Kameras Priekuḷu selekcijas stacijas labību, pākšaugu, linu un kartupeḷu cenu rādītājs 1937. gadam [Prices of Latvian Agriculture Board Priekuḷi breeding station cereals, pea, flax and potato for 1937]. Latvijas Lauksaimnieks, 2, 63-64 (in Latvian).

Anonymous (1966). Priekuḷ selekcijas un izmēǵinājumu stacija [Priekuḷi Plant Breeding and Experimental Station]. Latvijas PSR LM Zinātniski tehniskās informācijas un propagandas centrālais birojs. 20 lpp. (in Latvian).
Anonymous (1983). Priekulu selekcijas un izmēéinājumu stacija [Priekuli Plant Breeding and Experimental Station]. LPSR LM Zinātniski tehniskās informācijas pārvalde. 23 lpp. (in Latvian).

Bebre, G. (2003a). Kartupeḷu selekcijas līkloči [The road of potatoto breeding]. In: Priekuļu selekcijas stacija ceḷā uz simtagadi [Priekuli Plant Breeding Station on the Way to Centennial] (25.-31. 1pp.). Valmiera: Valmieras tipogrāfija Lapa (in Latvian).

Bebre, G. (2003b). Priekuḷi — lauksaimniecības zinātnes centrs Vidzemē [Priekuli - agricultural research center in Vidzeme]. In: Priekuḷ selekcijas stacija cel̦ā uz simtagadi [Priekuḷi Plant Breeding Station on the Way to Centennial] (6-15. lpp.). Valmiera: Valmieras tipogrāfija Lapa (in Latvian).

Bebre, G. (2003c). Priekuḷu selekcijas stacija — lauksaimniecības zinātnes centrs Vidzemē [Priekuḷi Plant Breeding Station - centre of agricultural science in Vidzeme] Agronomijas Vēstis, Nr. 5, 30- 36 (in Latvian).

Eihe, M., Priekule I. (2008). Baltijas Kultūraugu kaitēkḷu apkarošanas stacija Latvijas Augu aizsardzības pētniecības centrs 1913-2008 [Baltic crop Protection Centre 1913-2008]. Rīga: Puse-Plus, 71 1pp. (in Latvian).

Gaujers, V. (1983). Kartupeļu šķirnes un selekcija [Potato Varieties and Breeding]. Rīga: Zinātne. 58 lpp. (in Latvian).

Holms, I. (Ed.) (1992). Laukaugu selekcija Latvijā [Crop Breeding in Latvia]. Rīga: Avots, 190 lpp. (in Latvian).

Miglavs, U., Katajs-Paeglis, J., Bebre, G., Oša, M. (1991). Kartupeḷu selekcija [Potato breeding]. In: Augsne, selekcija, augkopība [Soil, Plant breeding, Plant production] (45.-47. lpp.). Rīga: Zvaigzne (in Latvian).

Sniedze, R. (1973) Priekuḷu selekcijas un izmēgeinājumu stacijas izaugsme [The development of Priekuli breeding and experimental station]. In: Zemkopja darba plauksmei [The Flourishment of Farmers Work] (5.-23. lpp.). Rīga: Zinātne (in Latvian).

Strazdina, V. (2012). History of wheat breeding in Latvia. Proc. Latvian Acad. Sci., 66 (1/2), 71-78.

Strods, H. (1992). Latvijas lauksaimniecības vēsture [The History of Latvian Agriculture]. Rīga: Zvaigzne. 287 lpp. (in Latvian).

Zarina, L. (2003a). Agrokīmijas laboratorijas izveidošana [The development of agrochemical laboratory]. Priekuḷu selekcijas stacija ceḷā uz simtagadi [Priekuli Plant Breeding Station on the Way to Centennial] (33.-34. lpp.). Valmiera: Lapa (in Latvian).

Zariņa, L. (2003b). Agrotehnikas nodal̨as vēsture [The history of department of crop mangment]. In: Priekulu selekcijas stacija celā uz simtagadi [Priekul,i Plant Breeding Station on the Way to Centennial] (39.-44. 1pp.). Valmiera: Lapa (in Latvian).

Zute, S., Belicka, I., Kalmans, Z. (2012). State Stende Cereal Breeding Institute: From the origins to the present. Proc. Latvian Acad. Sci., 66 (1/2), 59-70.

Аноним (1914). Отчеть о дъятельности дъятельность Рижскаго Центральнаго сельскохозяйственнаго общества 1913 годъ [Report on Activities of Riga Central Agricultural Society During 1913]. Рига: Burtnieks. 250 lpp. (in Russian).

\section{VALSTS PRIEKULU LAUKAUGU SELEKCIJAS INSTITŪTS — GADSIMTS LAUKSAIMNIECĪBAS PĒTIJUMOS UN SELEKCIJĀ}

Valsts Priekuḷu laukaugu selekcijas institūts (iepriekš Vendenes, Cēsu vai Priekuḷu izmēǵinājumu un selekcijas stacija) darbību sāka 1913. gadā. Galvenie darba uzdevumi gadsimta garumā palikuši nemainīgi: izpētīt dažādus lauksaimnieciskās ražošanas jautājumus un zināšanas nodot zemnieku rīcībā, kā arī veidot vietējiem audzēšanas apstākliem un patērētāju prasībām atbilstošas laukaugu šḳirnes. Nozīmīga darbības joma ir arī augstvērtīga laukaugu škirņu sēklas materiāla nodrošināšana lauksaimniekiem. Kopumā 31 laukaugu suga tika izmantota dažāda veida pêtījumos. Simt darbības gadu laikā selekcionāri izveidojuši vairāk kā 100 laukaugu škirnes. Zemnieku laukos labi pazīstamas Priekuḷos izveidotās kartupeḷu šḳirnes 'Brasla', “Agrie Dzeltenie', rudzu šḳirne 'Kaupo', zirṇu šḳirnes 'Vitra', 'Retrija, miežu šķirne 'Idumeja', kā arī vairākas āboliṇu un stiebrzāḷu šķirnes. Pēdējos gados Institūtā izveidota pirmā Baltijas valstīs kailgraudu miežu škirne 'Irbe', kā arī tritikāles škirne 'Inarta'. Vairāk kā 50 gadu pētījumi tiek veikti speciāli iekārtotā augu seku stacionārā. Ievērojami lauksaimniecības zinātnieki un selekcionāri strādājuši Priekuḷos: kartupeḷu selekcionāri E. Knappe, V. Gaujers, graudaugu selekcionāri J. Lindermanis, M. Gaiķe, M. Sovere, zāḷu selekcionāri P. Pommers, A. Apinis, I. Holms, zirņi selekcionāre M. Vitjažkova, agrotehnikas speciālisti R. Sniedze, V. Miḳelsons, zinātniskais vadītājs un direktors U. Miglavs un citi. 